\title{
INOVASI MODEL BIOINDUSTRI BERBASIS SAGU SPESIFIK LOKASI DI PAPUA
}

\author{
Niki Lewaherilla, Petrus A. Beding* \\ Balai Pengkajian Teknologi Pertanian Papua \\ Jl. Yahim Senatanino 49 Sentani Jayapura 99352 \\ *Corresponding author: peter.beding@gmail.com
}

\begin{abstract}
Abstrack: The Sago Bioindustry Agriculture Model produces food raw materials in the form of flour, and sago sugar food ingredients and the use of sago waste into organic fertilizer. The results of the business analysis show that sago starch, sago sugar and fertilizer products provide benefits for increasing farmers' income and are feasible to be developed each with a business feasibility level of $R$ / C sago flour $R$ / C (2.44) efficiency level for venture capital $40,8 \%$; sago sugar $R / C$ value of 2.81 with an efficiency level of $22.6 \%$ and sago waste organic fertilizer value of $R / C 1.3$ with a level of business capital efficiency of 76\%. The purpose of this research is to disseminate location-specific sago bioindustry technology innovation models in accordance with the SOP of quality sago flour production, sago-based food processing, and utilization of waste for fertilizer.
\end{abstract}

Keywords: bioindustry, model, sago, location-specific

\begin{abstract}
Abstrak: Model Pertanian Bioindustri sagu menghasilkan produk bahan baku pangan berupa tepung, dan bahan pangan gula sagu serta pemanfaatan limbah sagu menjadi pupuk organik. Adapun tujuan dari penelitian ini adalah untuk mendiseminasikan model inovasi teknologi bioindustri sagu spesifik lokasi sesuai dengan SOP produksi tepung sagu bermutu, pengolahan pangan berbasis sagu, dan pemanfaatan limbah untuk pupuk. Hasil analisis usaha menunjukan bahwa produk tepung sagu, gula sagu dan pupuk memberikan nilai manfaat bagi peningkatan pendapatan petani dan layak untuk dikembangkan masing-masing dengan tingkat kelayakan usaha $\mathrm{R} / \mathrm{C}$ tepung sagu $\mathrm{R} / \mathrm{C}(2,44)$ tingkat efisensi terhadap modal usaha $40,8 \%$; gula sagu nilai R/C 2,81 dengan tingkat efisiensi $22,6 \%$ dan pupuk organik limbah sagu nilai R/C 1,3 dengan tingkat efisiensi modal usaha sebesar $76 \%$.
\end{abstract}

Kata kunci: bioindustri, model, sagu, spesifik lokasi

\section{PENDAHULUAN}

Salah satu komoditas penting pertanian di Papua yang potensial dimanfaatkan untuk pengembangan pertanian bioindustri yaitu sagu. Tanaman sagu (metroxylon spp) digolongkan dalam suku Palmae, menghasilkan pati yang dapat dimanfaatkan untuk berbagai bahan baku industri pangan maupun non pangan. Menurut Wirakartakusumah (1984), pati sagu mengandung amilosa 27,4\% dan amilopektin $72,6 \%$. Perbandingan amilosa dan amilopektin mempengaruhi sifat kelarutan dan derajad gelatinisasi pati.
Pertanian bioindustri adalah usaha pengolahan sumberdaya alam pertanian dengan bantuan teknologi untuk menghasilkan berbagai macam produk yang bernilai ekonomi tinggi dan berwawasan lingkungan dengan menghasilkan produk yang bervariatif sehingga mampu meningkatkan manfaat ekonomi bagi petani dan keluarganya termasuk menghasilkan produk yang zero waste.

Sagu dikenal sebagai makanan pokok masyarakat Papua yang bermukim di wilayah pesisir dan lembah. Komoditas ini mempunyai peranan penting dari aspek sosial, ekonomi dan budaya masyarakat. Bagi masyarakat Papua, 
sagu basah diolah menjadi papeda dan pangan tradisonal lainnya berupa sagu lempeng dan sebagainya. Dengan adanya inovasi teknologi, sagu basah dapat diproses menjadi tepung sebagai bahan baku industri pangan baik aneka kue, mie/spageti, gula sagu dan sebagainya. Ampas hasil proses produksi tepung sagu mentah selanjutnya dapat dimanfaatkan sebagai pupuk, pakan ternak dan pakan ikan.

Lahan tanaman sagu di Papua sebagian besar berada pada hamparan hutan dan lahan sagu yang berada tidak jauh dari pemukiman berupa kebun sagu yang biasanya dimanfaatkan oleh masyarakat. Flach (1983), memperkirakan luas hutan sagu di Papua mencapai 980.000 ha dan kebun sagu 14.000 ha. Beberapa daerah di Provinsi Papua seperti Merauke, Sentani, Memberamo, Sarmi, Keroom dan Waropen dikenal sebagai daerah sentra produksi sagu yang potensial.

Jika diasumsikan luas kebun sagu di Papua 14.000 ha dengan setiap hektar terdapat 25 tanaman sagu matang fisiologis, maka dengan produktivitas $100 \mathrm{~kg}$ pati sagu kering /pohon potensi produksi pati adalah sebanyak 350.000 ton. 40 - $60 \%$ dari total potensi produksi pati sagu tersebut dapat dimanfaatkan untuk bahan pangan berupa bahan mie dan bahan baku kue, sedangkan sisanya dapat digunakan sebagai bahan non pangan. Menurut BBPT (1987), pemanfaatan mie sagu secara makro sebagai pengganti tepung terigu akan mengurangi impor terigu dan jika tepung sagu mengambil pangsa pasar $10 \%$ saja maka akan menghemat devisa negara hingga 2 triliun rupiah. Keunggulan mie sagu juga lebih awet dan lebih tahan lama dibandingkan mie terigu karena kandungan karbohdiratnya lebih tinggi.

Luas hutan sagu di Kabupaten Jayapura semakin menurun karena kebutuhan pemukiman, perkantoran dan pelebaran jalan. Data dan informasi luas luas hutan sagu yang semula 10.214 ha mengalami penuruanan luas areal menjadi 5.600 ha dan diperkirakan akan terus berkurang karena kebutuhan lahan pemukiman. Luas areal lahan sagu khususnya pada sentra sagu di kawasan Danau Sentani pada Distrik Ebungfau, Sentani Kota, Sentani Timur, Distrik Waibu dan Distrik Sentani Barat adalah sebesar 2.909,8 ha dan ulayat areal sagu terbesar berada pada ulayat kampung Yoboi, Kwadeware, Ifale, Dobonsolo, dan Doyo lama.
Pemanfaatan sagu di kawasan ini masih secara tradisional dan hanya untuk pemenuhan kebutuhan konsumsi rumah tangga sehari-hari berupa papeda dan sagu kering. Pengolahan menjadi tepung sagu belum banyak diusahakan dan dikembangkan oleh masyarakat, padahal apabila dibuat tepung sagu untuk bahan baku pangan akan memberikan nilai tambah yang signifikan dengan masa simpan tepung yang lebih lama dibandingkan dengan sagu mentah.

Sisa olahan sagu berupa limbah sagu yang masih potensial dapat dimanfaatkan sebagai pupuk dan pakan alternatif sebagai suplemen bagi ternak dan ikan. Limbah olahan sagu juga dapat dijadikan sebagai media tumbuh jamur, bahan baku briket, dan sebagainya. Pemanfaatan komoditas sagu untuk bahan baku pengolahan aneka pangan dengan demikian akan memberi dampak bagi peningkatan pemenuhan pangan dan gizi masyarakat sekaligus memenuhi selera dan kebutuhan konsumen terhadap produk yang dihasilkan juga berdampak pada peningkatan kesejahteraan bagi usahatani sagu. Limbah berupa sisa olahan juga dapat dijadikan sebagai produk pakan dan sebagainya.

Jika diasumsikan pemanfaatan lahan kebun sagu di Kabupaten Jayapura seluas 5.600 ha dan yang dapat dimanfaatkan seluas 2.500 ha serta terdapat 25 tanaman yang matang fisologis/ha dengan produktivitas setiap pohon/pati sagu kering $100 \mathrm{~kg} / \mathrm{ha}$, maka akan diperoleh 6.250 ton sagu.

Inovasi teknologi pengolahan tepung sagu berkualitas dan pemanfaatan limbah aneka pangan berupa mie sagu dan aneka kue sagu hasil inovasi Balitbangtan melalui kegiatan kajian teknologi pengolahan perlu didiseminasikan kepada stakeholder dalam berbagai wadah diseminasi diantaranya melalui bimtek dan pelatihan.

Adapun tujuan dari penelitian ini adalah untuk mendiseminasikan model inovasi teknologi bioindustri sagu spesifik lokasi sesuai dengan SOP produksi tepung sagu bermutu, pengolahan pangan berbasis sagu, dan pemanfaatan limbah untuk pupuk.

\section{METODE PENELITIAN}

\section{Lokasi dan Waktu}

Pengkajian dilaksanakan di Sentani Distrik Senatani Kabupaten Jayapura. Kajian dilakukan 
pada bulan April -Desember 2018. Kegiatan pengakajian mengunakan metode On Fram Research (OFR).

Bahan/materi yang digunakan untuk kegiatan pendampingan meliputi : a) teknologi pengolahan tepung dan olahan, b) penerapan teknologi pupuk organik berbasis sagu, c) melaksanakan bimbingan penerapan sesuai SOP, d) pelaksanaan demo gula cair, e) pengamatan terhadap penerapan diseminasi teknologi, f) monitoring dan evaluasi kegiatan, g) penyebaran materi leaflet kepada petani dan penyuluh yang melibatkan dinas terkait, petugas lapang, serta gapoktan/kelompok tani secara partisipatif.

\section{Metode Pelaksanaan Penelitian}

Prinsip dari konsep bioindustri adalah proses produksi yang mampu menghilangkan dampak polusi dan sekaligus menawarkan berbagai produk yang tidak merusak lingkungan. Konsep ini menyediakan berbagai siklus produk melalui proses produksinya yang tidak menghasilkan polusi dan tidak ada akhir dari sebuah produk setelah selesai digunakan, dan tidak menjadi sampah. Produk-produk dalam suatu proses akan menjadi residual yang tetap dapat digunakan kembali sebagai input bagi proses lainnya yang biasa disebut zero waste.

Pada kegiatan 2 tahun terakhir telah dilaksanakan penerapan model pemanfaatan tanaman sagu untuk menghasilkan produk tepung sagu dan olahan kue sagu dan pakan pada tahun pertama, kemudian dilanjutkan dengan menghasilkan tepung sagu bermutu dan olahan aneka kue sagu serta pemanfaatan limbah untuk bahan baku pakan di tahun kedua. Kegiatan tahun pertama dilaksanakan di kampung Yokiwa Sentani Timur dan tahun kedua tahun 2016 di Kampung Yakonde Distrik Waibu. Penerapan pada tahun 2017 diarahkan untuk diseminasi model melalui bimbingan teknis dan pelatihan SOP pengolahan tepung bermutu dan pupuk. Adapun pendekatan kegiatan adalah sebagai berikut :

\section{Pendekatan partisipatif}

Petani akan dijadikan rekan kerja serta sumber informasi untuk memperbaiki teknologi yang diintroduksikan dan pada akhir kegiatan akan dilakukan evaluasi umpan balik dari petani terhadap teknologi yang diintroduksikan.
Teknologi tersebut secara teknis mudah diterapkan, secara ekonomis menguntungkan dan secara sosial dapat diterima petani.

\section{Pendekatan teknologi}

Inovasi teknologi yang akan diintroduksikan yaitu hasil penerapan model selama 2 tahun berlangsung yang dilakukan BPTP Papua. Teknologi disesuaikan dengan teknologi yang ada di tingkat petani lalu kemudian dibandingkan dengan teknologi di petani (eksisting). Apabila petani belum menggunakan teknologi, maka teknologi Balit-Balit diterapkan sesuai dengan kondisi spesifik lokasi sehingga petani dapat atau mau mengadopsinya.

\section{Pendekatan ekonomi}

Teknologi pemeliharaan sagu yang akan diintroduksikan setelah dianalisa finansialnya diharapkan secara ekonomis dapat memberikan keuntungan bagi petani lokal.

\section{Pendekatan sosial}

Inovasi teknologi yang diintroduksikan dalam bimtek dan pelatihan secara ekonomi menguntungkan dan secara kultural dapat diterima masyarakat.

\section{Pengamatan dan Pengumpulan Data}

Data yang akan dikumpulkan adalah: 1) data sekunder yang meliputi potensi wilayah, potensi pasar, potensi usaha, dan swasta yang ada, 2) data primer yang dikumpulkan melalui pengumpulan langsung kepada responden (petani, kelompok, tokoh masyarakat formal / informal) dengan metode survei dan Focus Group Discussion (FGD), 3) hasil-hasil penelitian / pengkajian yang sudah ada dan data dasar wilayah atau sumber informasi lainnya yang menyangkut masalah dan paket teknologi yang akan diterapkan. Perakitan paket teknologi, serta data dan informasi dalam penerapan inovasi pengolahan sagu berupa penerapan teknologi pengolahan, produk dan produksi, biaya dan pendapatan hasil usaha, dan kelembagaan pasar produk sagu.

Analisis subjektivitas tepung sagu dan gula sagu berupa organoleptik produk (nilai $5=$ sangat suka, $4=$ suka, $3=$ cukup suka, $2=$ kurang suka, 1 = sangat kurang suka) dan produk olahan pangan sagu berupa gula sagu. 
Hasil wawancara responden selanjutnya akan dirata-rata, ditampilkan dan dideskripsikan.

Data dan informasi dalam penerapan model pertanian bioindustri sagu berupa penerapan teknologi, kondisi sosio budaya, biaya dan pendapatan hasil usaha, serta kelembagaan pertanian bioindustri sagu.

\section{Metode Analisis}

Data untuk analisis usaha pertanian bioindustri sagu diuraikan berdasarkan biaya-biaya dan penerimaan menggunakan $\mathrm{R} / \mathrm{C}$ ratio dan efisensi usaha. Analisis pendapatan dapat diformulasikan sebagaimana rumus

(Soekartawi, 1995)

$$
\mathrm{Pd}=\mathrm{TR}-\mathrm{TC}
$$

\section{Dimana :}

$\mathrm{Pd}=$ Pendapatan Pembudidaya sagu

$\mathrm{TR}=$ Total Revenue $($ Total Penerimaan $)$

$\mathrm{TC}=$ Total Cost $($ Total Biaya $)$

Analisis R/C ratio merupakan alat analisis untuk melihat keuntungan relatif suatu usaha dalam satu tahun terhadap biaya yang dipakai dalam kegiatan tersebut. Suatu usaha dikatakan layak apabila nilaiR/C lebih besar dari $1 \quad(\mathrm{R} / \mathrm{C}>1)$. Hal itu menggambarkan semakin tinggi nilai $\mathrm{R} / \mathrm{C}$ maka tingkat keuntungan suatu usaha juga akan semakin tinggi.

$$
\mathrm{R} / \mathrm{C}=\frac{\text { Total penerimaan }}{\text { Total biaya }}
$$

Adapun kriteria pengambilan keputusannya adalah sebagai berikut :

$\mathrm{R} / \mathrm{C}>1$ : maka usaha layak untuk dikembangkan/menguntungkan

$\mathrm{R} / \mathrm{C}=1 \quad$ : usaha tidak untung dan tidak rugi

$\mathrm{R} / \mathrm{C}<1$ : usaha rugi dan tidak layak diusahakan.

Efisiensi modal usaha dilakukan pada setiap komponen usaha tepung sagu, produksi gula sagu, pupuk organik menggunakan rumus (3) (Soekartawi, 1995)

$$
\mathrm{EP}=\frac{\mathrm{BP}}{\mathrm{NP}} \times 100 \%
$$

Dimana :

$$
\begin{array}{ll}
\mathrm{EP} & =\text { Efisiensi Modal } \\
\mathrm{BP} & =\text { Biaya-biaya produksi } \\
\mathrm{NP} & =\text { Nilai Produksi yang dipasarkan }
\end{array}
$$

\section{HASIL DAN PEMBAHASAN}

Penerapan inovasi model pertanian bioindustri berbasis sagu mempertimbangkan kondisi spesifik sosiobudaya, ekonomi, lingkungan dan eksisting pemanfaatan sagu oleh masyarakat setempat. Pemanfaatan sagu sebatas bahan pangan dijadikan papeda, sinoli dan sagu kering, padahal sagu sangat potensial dijadikan bahan baku pangan berupa tepung yang memiliki nilai tambah dari aspek keaneragaman pangan sekaligus sebagai sumber perolehan pendapatan.

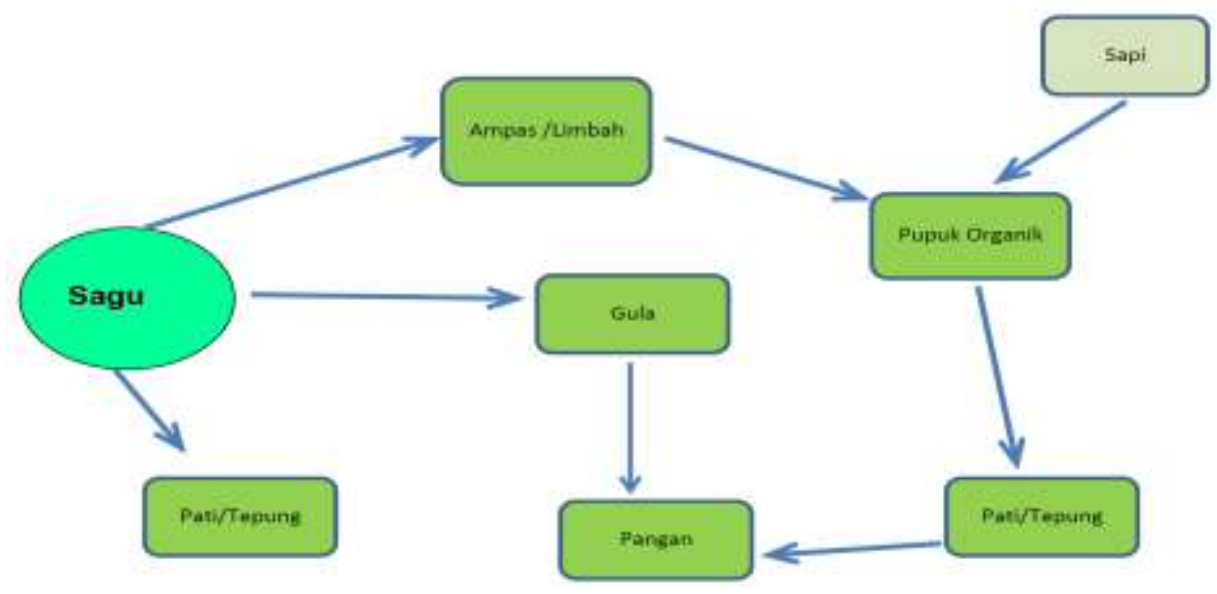

Gambar 1. Model Bioindustri Pertanian Berbasis Sagu 
Penerapan teknologi menghasilkan produk pangan dari sagu, memanfaatkan limbah olahan sagu untuk pakan serta produk turunan lainnya. Inovasi teknologi tersebut melalui pembinaan dan pendampingan secara kontinu serta didukung inovasi kelembagaan akan memberikan manfaat dalam pengembangan pemanfaatan sagu sebagai komoditas strategis dan memiliki multi manfaat bagi masyarakat.

Kegiatan model pertanian bioindustri sagu tahun 2017 merupakan satu kesatuan dalam sistem produksi komoditas sagu yang terbagi dalam sub sistem inovasi produk tepung sagu, pengolahan pangan dan pemanfaatan limbah. Produksi tepung sagu terutama pada tahapan ekstraksi sagu menggunakan alat ekstraksi. Pemanfaatan pangan berbasis sagu melalui inovasi gula sagu dan pemanfaatan limbah menghasilkan pupuk organik.

\section{Inovasi Teknologi Produksi Pangan dan Pemanfaatan Limbah}

Pengolahan tepung sagu menjadi bahan baku utama olahan pangan berbasis sagu seperti mie, kue dan olahan sebagainya belum banyak dilakukan oleh petani lokal. Di sisi lain, dengan adanya pengolahan tepung sagu akan memberikan nilai tambah bagi petani antara lain masa simpan tepung semakin panjang, memudahkan untuk dikemas dan transportasi, harga jual lebih tinggi dan keunggulan lainnya.

Dengan semakin meningkatnya bisnis kuliner maka permintaan akan tepung terigu juga akan semakin meningkat. Tepung terigu yang berasal dari gandum merupakan komoditas impor, padahal dilain pihak berbagai komoditas pangan berupa sagu dan umbiumbian dapat dijadikan bahan baku tepung yang dapat menjadi substitusi tepung terigu.

Data asosiasi produsen terigu (Aptindo) bahwa pada bulan Januari-Juni 2016 jumlah impor terigu adalah sebesar 97.349.000 ton dengan nilai sebesar US\$28,22 juta. Dengan demikian, jika produksi tepung sagu dapat ditingkatkan maka jumlah impor tepung gandum/terigu diperkirakan dapat berkurang. Meningkatnya pertumbuhan konsumsi tepung terigu karena perkembangan industri makanan seperti mie instan, biskuit, roti dan produk lain yang berbasis tepung terigu mencapai sebesar $26 \%$. Dengan demikian potensialnya tepung sagu sebagai bahan baku pangan juga sebagai bahan substitusi tepung terigu dalam pengolahan aneka pangan .

Harga tepung sagu di pasaran wilayah kota Jayapura dan sekitarnya sebenarnya masih cukup tinggi, yaitu sebesar Rp. 30.000 sampai $\mathrm{Rp} 35.000$ per $\mathrm{kg}$. Hal ini karena produksi tepung masih rendah dan nilai ekslusif tepung sagu sebagai bahan pangan organik. Potensi pasar tepung sagu dengan demikian cukup menjanjikan untuk dikembangkan oleh masyarakat lokal maupun masyarakat lainnya di wilayah sentra produksi sagu.

Beberapa faktor penting yang perlu dipertimbangkan untuk menghasilkan produk tepung sagu yang bermutu antara lain; 1) jenis sagu, 2) tingkat kematangan sagu, serta 3) proses pengolahan yang menjamin sanitasi dan higienis produk.

Masyarakat lokal penghasil sagu pada umumnya sudah memahami jenis sagu dan tingkat kematangannya untuk dipanen. Namun dalam proses pengolahan pada tahapan ekstraksi, masyarakat kurang memperhatikan hiegienis dan sanitasi lingkungan sehingga berdampak pada mutu sagu. Hal ini karena proses produksi sagu mentah memanfaatkan air yang kurang dan tidak hiegienis di lokasi kebun sagu, seperti menggunakan sumberdaya air sungai atau anak sungai maupun air tergenang di wilayah sekitar kebun sagu yang dari aspek kebersihan kurang terjamin dan berdampak pada mutu produk.

Proses produksi yang dilakukan secara tradisional / manual dapat mengurangi perolehan hasil yang optimal. Hasil perhitungan menunjukkan bahwa tingkat kehilangan hasil dalam proses produksi sagu mentah berkisar antara 10 - 20\% yang tentunya berdampak pada perolehan pendapatan. Jika rata-rata produksi dalam 1 bulan sebanyak empat dengan rata-rata produksi sagu mentah sebanyak $250 \mathrm{~kg} /$ pohon atau $1.000 \mathrm{~kg} / \mathrm{bulan}$, maka tingkat kehilangan hasil sebesar 100 $200 \mathrm{~kg}$ sagu basah atau setara dengan $\mathrm{Rp}$ 150.000 sampai $\mathrm{Rp} 300.000$ per bulan.

Introduksi inovasi bioindustri tepung sagu dalam proses ekstraksi pati tepung basah menggunakan alat atau mesin bertujuan untuk menghasilkan pati sagu yang menekan kehilangan hasil sehingga produksi yang diperoleh optimal sekaligus mempercepat waktu kerja dibandingkan dengan sistem manual/tradisional. 


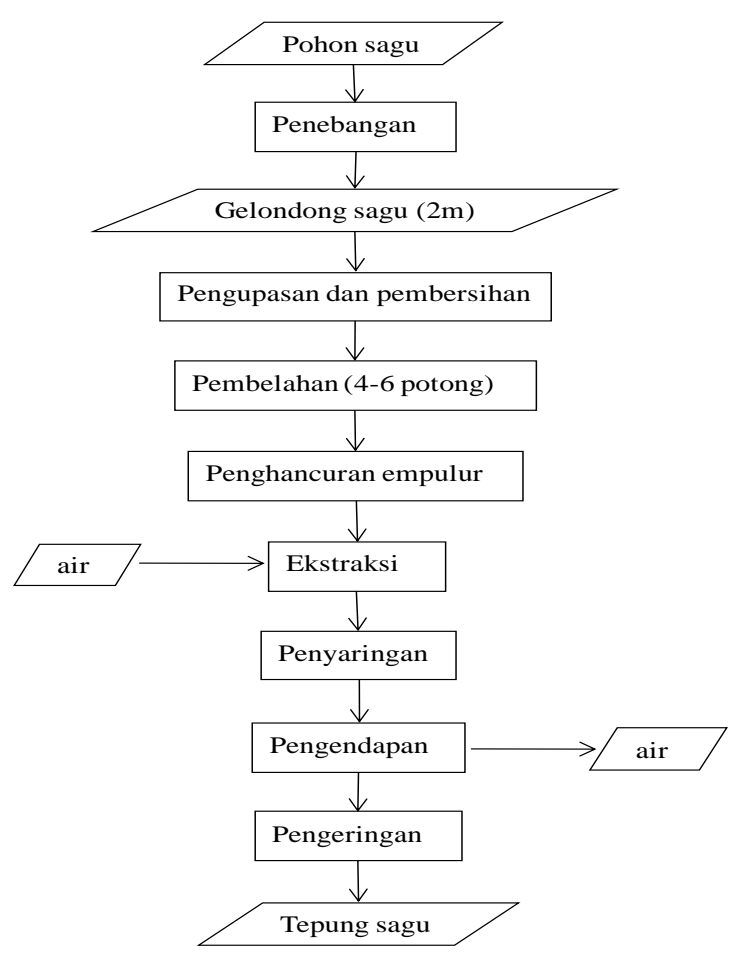

Gambar 2. Diagram Pembuatan Tepung Sagu

Hasil kajian menunjukkan bahwa kapasitas ekstraksi sebanyak $300 \mathrm{~kg}$ hancuran empulur/jam dan tingkat kehilangan hasil/pati terikut ke ampas 0,9-2.0\%, dimana bagianbagian lain dari alat pengekstrak ini adalah : Gear box (WPX-80), saluran pengeluaran pati, dan bak penampung pati. Hasil pembuatan tepung sagu pada tahapan ekstraksi sagu hingga proses pengendapan menggunakan alat ekstraksi dapat dilihat pada Gambar 2.

Hasil penilaian produksi tepung secara subjektif terhadap mutu tepung sagu yang diamati sesuai dengan standar SNI tepung sagu. Tepung sagu yang dihasilkan oleh koperator dengan kriteria warna, bau, rasa dan bentuk tepung termasuk kategori normal dan disukai. Hasil ayakan pada ukuran mesh 100 seluruh tepung dapat lolos, dengan demikian memenuhi standar kualitas dari SNI tepung sagu. Lama penyimpanan tepung sagu adalah selama $>1$ bulan juga tidak terdapat serangga dan benda asing. Dengan demikian secara organoleptik mutu tepung sagu yang dihasilkan memenuhi kualitas/mutu yang baik. Khusus jenis sagu tertentu diperoleh warna tepung sagu putih agak coklat kemerahan hal ini karena empulur sagu berwarna merah sehingga setelah diolah menjadi tepung berwarna coklat .

Salah satu faktor penting mengukur efektifitas perolehan produksi sagu yaitu curahan waktu kerja. Perhitungan curahan waktu proses produksi mulai pada tahapan penghancuran empulur, peremasan empulur hingga perolehan sagu mentah pada pengolahan manual tradisional dengan penggunaan alat/mesin.

Hasil lapangan menunjukkan bahwa rata-rata produksi pati sagu dari 1 pohon sagu yang matang dikerjakan oleh 2 orang tenaga kerja. Setelah pohon ditebang, pembelahan dan pembersihan gelondong menjadi 4 bagian kemudian dilakukan penghancuran empulur menggunakan mesin /alat rata-rata curahan waktu 1,5 -2 jam. Kemudian pada tahapan ekstraksi juga menggunakan alat dan membutuhkan waktu sekitar 3-5 jam. Tepung basah selanjutnya dijemur di bawah sinar matahari selama 2 hari dan membutuhkan waktu pengeringan sekitar 5-6 jam/hari. Cara manual tradisional petani lokal membutuhkan waktu lebih lama jika dibandingkan menggunakan alat ekstraksi (Tabel 1).

Jumlah produksi hasil ekstraksi sagu mentah yang dihasilkan dari 1 pohon sagu sebanyak 250-300 Kg, sedangkan cara manual kebiasaan masyarakat untuk produksi pati basah rata-rata diperoleh sebanyak $200-240 \mathrm{~kg}$ basah atau setelah dikeringkan selama 2 hari pada sinar matahari akan diperoleh pati/tepung sagu sebanyak $125 \mathrm{~kg}-150 \mathrm{~kg}$ tepung adapun manual sebanyak 100-120 kg pati/tepung.

Tabel 1. Perbandingan Curahan Kerja Pengunaan Alat / Mesin dengan Cara Manual Tradisional.

\begin{tabular}{cccccc}
\hline Sistem & $\begin{array}{l}\text { Penebangan/pe } \\
\text { mbelahan (jam) }\end{array}$ & $\begin{array}{l}\text { Penghancuran } \\
\text { Empulur } \\
\text { (jam) }\end{array}$ & $\begin{array}{l}\text { Ekstraksi } \\
\text { Penyaringan, } \\
\text { pengendapan } \\
\text { (jam) }\end{array}$ & $\begin{array}{l}\text { Pengeringan } \\
\text { (sinar Matahari) } \\
\text { (jam) }\end{array}$ & $\begin{array}{l}\text { Jumlah } \\
\text { (jam } \\
\text { Kerja) }\end{array}$ \\
\hline Alat/Mesin & $1-2$ & $1,5-2$ & $3-5$ & 2 hari ( 10-12 & $15,5-21$ \\
$\begin{array}{l}\text { Manual } \\
\text { tradisional }\end{array}$ & $1-2$ & $3-5$ & $10-12$ & 2 hari (10-12) & $24-31$ \\
\hline
\end{tabular}

Sumber : Data primer, 2017 
Apabila diasumskan bahwa dalam 1 ha terdapat 100 pohon sagu maka akan menghasilkan pati basah sebanyak 200-300 ton atau setara 100-150 ton tepung sagu. Beberapa produk yang dihasilkan dari penerapan inovasi model bioindustri sagu terdiri dari :

\section{a. Produk pengolahan gula sagu}

Gula merupakan salah satu kebutuhan pokok bagi masyarakat dan industri makanan dan minuman. Seiring dengan kemajuan teknologi dan tuntutan akan efisiensi, penggunaan gula kristal dirasa menjadi kurang menguntungkan dibanding dengan gula cair.

Sagu merupakan tanaman penghasil karbohidrat yang paling produktif. Produksi gula cair/glukosa dari sagu sangat potensial untuk memenuhi kebutuhan pangan keluarga dan masyarakat lokal. Pengolahan gula sagu dapat dilakukan dalam skala rumah tangga.

Pati sagu selain sebagai bahan pangan pokok potensial untuk dijadikan bahan baku gula cair. Menurut Bintoro et al (2013), sagu dapat dijadikan alternatif bahan baku pembuatan HFS (high fructosa syrup) yang diminati oleh industri makanan dan minuman untuk mensubtitusi sukrosa, siklamat, dan sakarin.

Schuiling (2009) dalam Budiyanto (2015) menyatakan bahwa pati sagu dari Indonesia mengandung $81-88 \%$ karbohidrat (27\% amilosa dan $73 \%$ amilopektin), 10-17\% air, $0.31 \%$ protein, $0.11-0.25 \%$ lemak, $1.35 \%$ serat dan $0.15-0.28 \%$ abu.

Produksi sagu yang dikelola dengan baik dapat mencapai 20-40 ton pati kering/ha/tahun. Produktivitas tersebut setara dengan tebu, namun lebih tinggi dibandingkan dengan ubi kayu dan kentang dengan produktivitas pati kering $10-15$ ton pati kering/ha/tahun (Bintoro et al. 2010).

Inovasi produk gula cair dengan demikian dapat diterapkan dan layak untuk konsumsi, denhan standar pengolahan pangan yang sesuai dengan inovasi dan SOP yang hiegienis. Adapun prosedur pengolahan gula cair sagu disajikan pada Gambar 3.

Berdasarkan Gambar 3, produksi gula cair sagu dilakukan melalui beberapa tahapan yaitu pencampuran pati sagu dengan air, likuifikasi, sakarifikasi, pemanasan, penyaringan (penjernihan) dan penguapan.

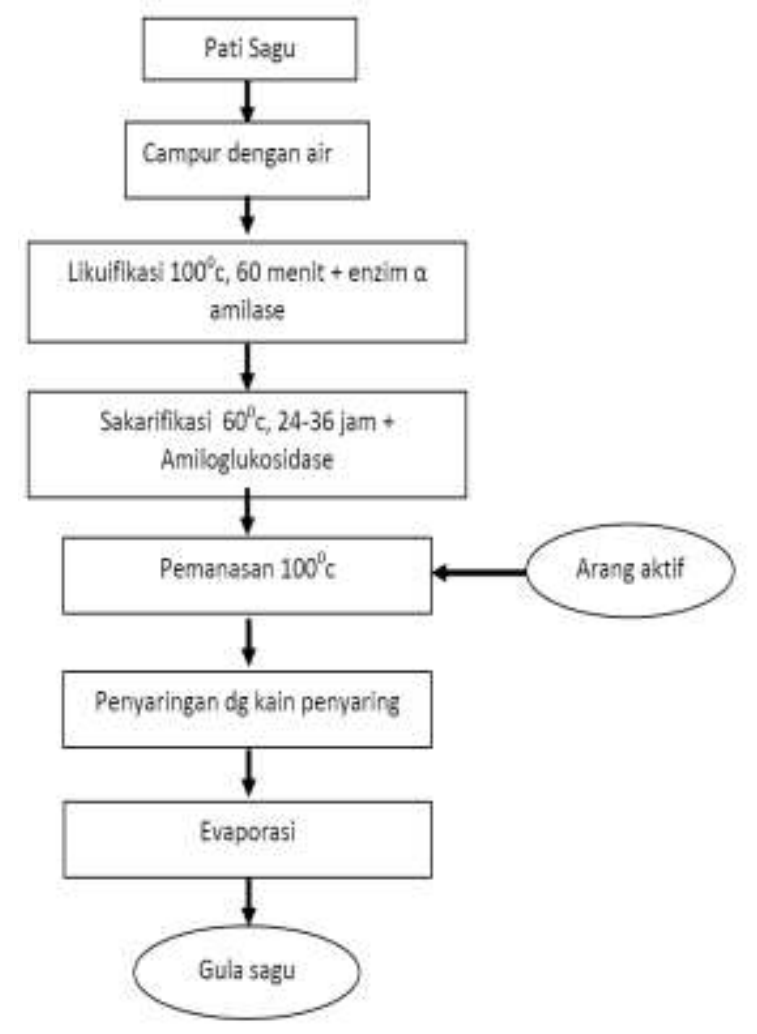

Gambar 3. Proses Produksi Gula Cair Sagu

Pencampuran air dengan pati bertujuan untuk mempermudah proses gelatinisasi dan proses enzimatis. Pencampuran dilakukan dengan pengadukan agar menjadi suspensi yang homogen. Tahapan selanjutnya adalah likuifikasi, yaitu proses hidrolisis pati menjadi dekstrin dengan menambahkan enzim $\alpha$ amilase pada suhu di atas suhu gelatinasi dengan $\mathrm{pH}$ optimum. Suhu kemudian dipertahankan pada $100^{\circ} \mathrm{C}$ dengan $\mathrm{pH} 4,0-7,0$ yang bertujuan untuk pemasakan sirup sampai amilosa dapat terdegradasi menjadi dekstrin.

Proses berikutnya adalah sakarifikasi, yaitu proses hidrolisis dekstrin menjadi glukosa. Pati yang telah terdegradasi menjadi dekstrin selanjutnya diturunkan suhunya dari $100^{\circ} \mathrm{C}$ menjadi $50-60^{\circ} \mathrm{C}$, kemudian dilakukan penambahan enzim amiloglukosidase yang berfungsi untuk memecah rantai dekstrin menjadi glukosa pada $\mathrm{pH}$ 4,0-4,6. Proses sakarifikasi tersebut membutuhkan waktu maksimal 76 jam, tetapi waktu tersebut dapat dipersingkat sesuai dengan waktu yang diharapkan dengan penambahan lebih banyak enzim ke dalam suspensi sampai mencapai nilai dextrin equivalen minimal $98 \%$. 
Tahap selanjutnya dilakukan proses pemucatan (pemanasan dengan penambahan arang aktif), penyaringan dan penguapan (evaporasi). Pemucatan bertujuan untuk menghilangkan bau, warna, dan kotoran, serta menghentikan aktivitas enzim. Absorben yang digunakan adalah karbon aktif sebanyak 0,5$1 \%$ dari bobot pati. Penyaringan dilakukan dua tahap yaitu penyaringan arang aktif dengan kain dan penyaringan kotoran koloid dengan resin. Penyaringan arang aktif bertujuan untuk memisahkan karbon aktif yang tertinggal, dan kotoran yang belum terserap oleh karbon aktif. Penyaringan kotoran koloid dilewatkan pada kolom berisi resin penukar ion sehingga ion-ion logam yang tak diinginkan dapat dipisahkan dengan gula cair sagu. Tahap terakhir adalah penguapan yang dilakukan untuk mendapatkan sirup glukosa dengan kekentalan seperti yang dikehendaki $40-50^{\circ}$ Brix. Tahapan ini menggunakan wajan penggorengan dan semakin tinggi suhu yang digunakan maka warna sirup yang dihasilkan semakin coklat kehitaman. Hal tersebut terjadi karena pada suhu tinggi glukosa akan mengalami karamelisasi dan proses penguapan bertujuan untuk memekatkan glukosa.

Hasil analisis uji organoleptik skala (1 5) indikator penilaian sangat tidak suka s/d sangat suka terhadap rasa, warna, dan bau gula cair oleh panelis antara suka dan sangat suka. Gula cair yang bersumber dari sagu ini akan memiliki banyak keuntungan diantaranya : a) Ekonomis, praktis dan higienis; b) Lebih segar dan tahan lama; c) Menambah tekstur dan kekentalan; d) Tanpa bahan kimia; e) Berfungsi sebagai pemanis, sirup dan rasa sekaligus; f) Rendah glikemik indeks; g) Bebas gluten; h) Bebas dari kotoran; i) Bebas dari fruktosa tinggi; i) Larut langsung dalam minuman panas dan dingin atau makanan; k) Pengerjaannya sederhana dapat diterapkan dalam skala rumah tangga

\section{b. Pupuk organik limbah sagu}

Ampas sagu berpotensi sebagai sumber bahan organik untuk meningkatkan kesuburan tanah. Pengaruh ampas sagu terhadap kesuburan tanah ditentukan oleh tingkat dekomposisi dan komposisinya.

Menurut Bintoro et al. (1990), sebagian besar material berupa kulit dan ampas terbuang sebagai sisa produk. Persentase pemanfaatan yang sangat kecil ini merupakan pemborosan sumberdaya alam. Hasil ikutan ampas pengolahan sagu, apabila dibiarkan dapat menimbulkan pencemaran lingkungan berupa bau dan peningkatan kemasaman tanah $(\mathrm{pH}<$ 4), yang dapat menghambat pertumbuhan, bahkan menyebabkan kematian tanaman. Kandungan nutrisi di ampas sagu termasuk rendah, dengan komposisi $0,62 \%$ protein kasar, 0,4 \% lemak, 4,65\% abu, dan 72,45\% pati (Bintoro et al., 1990). Oleh karena itu, dengan inovasi teknologi limbah olahan berupa ampas dapat dimanfaatkan sebagai pupuk organik bagi tanaman.

Satu batang pohon sagu pati menghasilkan sekitar 16-28\% dari bobot total batang sagu yang termanfaatkan, dengan demikian limbah yang dapat termanfaatkan untuk pupuk organik cukup potensial untuk usaha budidaya pertanian pangan.

Ekstraksi fraksi padat untuk mengeluarkan pati dari batang sagu yang dihancurkan membutuhkan air. Proses ini dilakukan berulang-ulang untuk mendapatkan sebanyak mungkin pati, dan menyisakan limbah berupa ampas sagu (ela sagu) dan limbah cair. Keduanya masih mengandung sejumlah substansi penting sehingga dapat dimanfaatkan sebagai input organik dalam pertanian berkelanjutan. Penggunaan limbah sagu tidak hanya sekedar mengurangi polusi pengolahan sagu tetapi juga menyediakan solusi ekonomis untuk pengelolaan limbah sagu. Jika diasumsikan dalam kawasan sagu seluas 1 ha terdapat 100 pohon sagu dan 1 pohon sagu yang menghasilkan $200-300 \mathrm{~kg}$ pati basah menghasilkan sebanyak $40-60 \%$ ampas sagu dari keseluruhan pohon, maka limbah sagu yang dapat termanfaatkan adalah sebanyak $18-20$ ton/ha.

\section{Analisis Kelayakan Usaha}

Pertanian bioindustri sagu menghasilkan produksi pangan, pakan dan produk samping lainnya berwawasan lingkungan dan memberikan keuntungan finansial. Model pertanian bioindustri berbasis sagu tahun 2017 menghasilkan produk utama berupa tepung sagu, dan derivatnya berupa gula sagu serta pemanfaatan limbah olahan sebagai pupuk organik.

Analisis kelayakan usaha dimaksudkan untuk menilai sejauh mana manfaat yang dapat 
diperoleh dalam melaksanakan suatu kegiatan usaha. Kelayakan usaha dalam pertanian bioindustri sagu harus memberikan manfaat dalam arti finansial maupun sosial benefit. Dengan adanya analisis kelayakan ini diharapkan resiko kegagalan dalam memasarkan produk dapat dihindari.

\section{a. Analisis usaha tepung sagu}

Hasil lapangan menunjukan bahwa dari aspek respon pasar terhadap produk pangan berbasis sagu sangat berpeluang terutama aneka pangan olahan sagu maupun tepung sebagai bahan baku olahan pangan .Di Pasar Sentani dan sekitarnya harga jual sagu basah satu karung 20 kg sebesar Rp. 200.000 sampai Rp 300.000, sedangkan harga jual tepung sagu / pati sagu sebesar Rp 30.000 sampai Rp 35.000/kg, jika dibandingkan dengan tepung terigu yang hanya seharga Rp 12.000/kg, maka harga tepung sagu kurang kompetetif untuk produksi pengolahan pangan. Namun nilai eklusivitas sagu sebagai pangan produk organik dan menjamin kesehatan konsumen menjadikan produk sagu memiliki nilai yang tinggi yang juga sudah banyak disajikan di restoran-restoran. Aspek teknis produk olahan sagu disajikan pada Tabel 2.

Pangan berbasis sumberdaya pangan lokal berupa sagu dapat dijadikan berbagai produk pangan yang bervariatif dan beraneka untuk dijadikan oleh-oleh berupa penganan basah, penganan kering, keripik dan berbagai produk yang dikemas baik, menarik dan informatif. Demikian pula limbah dari biomassa sagu maupun limbah olahan sagu dapat dijadikan produk pupuk dan produk lainnya yang dapat memberikan manfaat finansial bagi masyarakat. Pemanfaatan sebagai pupuk akan menguarangi biaya usahatani.

Analisis usahatani didasarkan pada biaya dan penerimaan usahatani. Biaya usahatani bioindustri berbasis sagu terdiri dari biaya tetap dan biaya variabel.

Tabel. 2. Analisis Usaha Tepung Sagu oleh Koperator

\begin{tabular}{|c|c|c|}
\hline Uraian & Volume & Total (Rp) \\
\hline \multicolumn{3}{|l|}{ 1. Biaya/ Pengeluaran } \\
\hline Biaya Tetap & & 7.800 .000 \\
\hline a. Mesin pengolah sagu (pangkur sagu) & 1 unit @ Rp 8.500.000 ( 3 tahun) & 2.800.000/tahun \\
\hline b. Biaya Pemeliharaan & 1 tahun @ Rp 1.000.000 & 1.000 .000 \\
\hline $\begin{array}{l}\text { c. Peralatan bantu (parang, linggis, gerobak, } \\
\text { perlengkapan kerja, ember, baskom) }\end{array}$ & 1 paket @ Rp 2.000.000 (2 tahun) & 1.000.000/tahun \\
\hline d. Peralatan pengolah Pati/pengolahan tepung & 1 paket @ Rp.20.000.000 (5 tahun) & 4.000.000/tahun \\
\hline Biaya Variabel & & 29.000 .000 \\
\hline a. Kemasan & $1000 \times \operatorname{Rp} 3.000$ & 3.000 .000 \\
\hline b. BBM & $24 \times 20$ liter $\times \operatorname{Rp} 7.000$ & 1.400 .000 \\
\hline c. Konsumsi & $24 \times \operatorname{Rp} 300.000$ & 7.200 .000 \\
\hline d. Upah Penebangan, pembersihan, pemotongan & $24 \times 3$ orang x Rp 100.000 & 7.200 .000 \\
\hline e. Upah penjemuran & 3 orang $\times \mathrm{Rp} 100.000 \times 24 \mathrm{OH}$ & 7.200 .000 \\
\hline f. Biaya ijin dll & Rp 1.000.000/tahun & 1.000 .000 \\
\hline g. Biaya bahan bantu & 1 paket /tahun $\operatorname{Rp} 2.000 .000$ & 2.000 .000 \\
\hline Total Biaya & & 36.800 .000 \\
\hline \multicolumn{3}{|l|}{ 2. Penerimaan } \\
\hline a. Produksi tepung sagu & 3.000 kg x @ Rp.30000 & 90.000 .000 \\
\hline b. Pendapatan & Penerimaan Produksi - Total Biaya & 53.200 .000 \\
\hline $\mathrm{R} / \mathrm{C}$ & & 2,44 \\
\hline BEP Produksi & $53.200 .000 / 30000$ & $1.773 \mathrm{~kg}$ \\
\hline BEP Harga & $53.200 .000 / 3000 \mathrm{~kg}$ & Rp. 17.750 \\
\hline Pay Back Period & $53.200 .000 / 36.800 .000$ & 17 bulan \\
\hline Efisensi Modal & $36.800 .000 / 90.000 .000 \times 100 \%$ & $40,88 \%$ \\
\hline
\end{tabular}

Sumber : Data primer, 2017 
Pada Tabel 2, hasil analisis usaha menunjukkan bahwa biaya produksi tepung sagu oleh koperator dari hulu-hilir proses produksi secara total sebesar Rp 36.800.000/tahun terdiri dari biaya modal tetap sebesar Rp 7.800.000, dan biaya variabel sebesar Rp. 29.000.000. Menurunnya biaya produksi karena penggunaan alat ekstraksi tepung sagu dibandingkan dengan manual.

Hasil analisis usaha pengolahan tepung sagu dari Tabel 2 menujukkan bahwa dengan produksi tepung sebanyak kurang lebih 3000 $\mathrm{kg} /$ tahun dengan harga jual Rp.30.000,-/kg akan menghasilkan nilai produksi /penerimaan bruto sebesar Rp. 90.000.000,-/tahun dan perolehan pendapatan setelah dikurangi biaya total maka pendapatan bersih bersih Rp. 53.200.000,- Dengan nilai R/C Ratio sebesar $2,44(\mathrm{R} / \mathrm{C}>1)$. Agar petani dapat merancang tingkat produksi dan keuntungan yang ingin diperoleh maka dilakukan perhitungan titik impas (BEP) sebagai langkah strategis mensiasati usaha secara kontinu. Hasil perhitungan menunjukkan bahwa usaha pengolahan tepung tidak untung dan tidak rugi pada produksi tepung sagu sebanyak $1.773 \mathrm{~kg}$ demikian pula pada harga jual BEP senilai Rp $17.750 / \mathrm{kg}$, dengan demikian produsen dapat mempertimbangkan perolehan keuntungan dan jumlah produksi minimal memenuhi manfaat ekonomi yang ingin dicapainya.

Berdasarkan efisensi modal dalam usaha produksi tepung oleh masyarakat /kelompok usaha, nilai efisensi modal adalah sebesar $40,88 \%$ dan hal ini menunjukkan bahwa usaha produksi tepung sagu sangat efisen.

\section{b. Analisis usaha pengolahan gula sagu}

Salah satu produk turunan olahan pangan dari tepung sagu adalah gula sagu, sebagai salah satu produk yang dapat diandalkan mengingat kebutuhan pemenuhan pangan dan gizi masayarakat. Pada satu batang pohon sagu terdapat $500 \mathrm{~kg}$ tepung basah dan dapat menghasilkan tepung sagu sebanyak $150 \mathrm{~kg}$ tepung sagu, tergantung dari jenis dan besar kecilnya diameter batang sagu. Apabila dijadikan gula sagu dengan komposisi $1 \mathrm{~kg}$ tepung sagu dapat mengasilakan gula sagu sebayak $600-750 \mathrm{ml}$ gula sagu. Analisis usaha produk gula sagu didasarkan pada biaya dan penerimaan disajikan pada Tabel 3 .

Tabel 3 menunjukkan bahwa biaya produksi pada analisis usaha produksi gula sagu adalah sebesar Rp 13.100.0000, terdiri dari biaya tetap peralatan pengolahan sebesar Rp 3.000.000 dengan masa pakai peralatan selama 3 tahun sehingga biaya setahun sebesar Rp 100.000.000/produksi (7,7\%). Biaya variabel terdiri dari biaya bahan, kemasan dan upah tenaga kerja sebesar $\mathrm{Rp} 12.100 .000$ $(92,3 \%)$. Berdasarkan rasio $\mathrm{R} / \mathrm{C}$ diperoleh nilai kelayakan usaha 3,81. Hal ini berarti bahwa dalam setiap biaya produksi gula sagu sebesar $\mathrm{Rp} 1$ diperoleh penerimaan $\mathrm{Rp}$ 3,81 atau perolehan pendapatan bersih manfaat bagi

Tabel 3. Analisis Usaha Produksi Gula Sagu/Unit Produksi Rumah Tangga/Tahun

\begin{tabular}{llr}
\hline Uraian & Volume & Total (Rp) \\
\hline Biaya & & \\
1. Biaya Tetap & & 3.000 .000 \\
$\begin{array}{l}\text { Peralatan pengolahan Pangan dan dan } \\
\text { peralatan bantu lainnya ( umur ekonomis } 3\end{array}$ & 1 paket & $(1.000 .000$ \\
tahun & & $/$ thn $)$ \\
2. Biaya Variabel & & 11.100 .000 \\
a. bahan baku tepung sagu & $500 \mathrm{Kg}$ & 6.000 .000 \\
b. bahan enzim & 1 paket & 500.000 \\
c. kemasan & 1 paket & 2.000 .000 \\
d. upah tenaga kerja & 3 OP x 100.000 x 12 bulan & 3.600 .000 \\
& & 12.100 .000 \\
Total Biaya (1 + 2) setiap produksi & & 13.100 .000 \\
Penerimaan produksi & 500 kemasan ukuran 250 gr @ & 50.000 .000 \\
Pendapatan Bersih & 10.000 & 36.900 .000 \\
R/C & & 2,81 \\
Efisensi Modal & & $26,2 \%$ \\
\hline
\end{tabular}

Sumber : Data primer, 2017 
Tabel 4. Analisis Usaha Pupuk Organik Berbasis Limbah Sagu

\begin{tabular}{lrr}
\hline Uraian & Volume & Total (Rp) \\
\hline Biaya & & \\
1. Biaya Tetap & & $1.000 .000(2$ tahun $)$ \\
$\quad$ Peralatan pendukung dll & 1 paket & 500.000 \\
2. Biaya Variabel & & 1.400 .000 \\
a. bahan baku ampas sagu & $500 \mathrm{~kg} @$ Rp.500 & 250.000 \\
b. kotoran sapi & $100 \mathrm{Kg} @$ Rp.500 & 250.000 \\
c. bahan pendukung dan bahan bantu & 1 paket & 100.000 \\
d. Karung & 250 @ Rp.1000 & 250.000 \\
e. tenaga kerja & 2 Orang @ Rp 75.000 x 4 hari & 600.000 \\
Total Biaya (1+2) setiap produksi & & 1.900 .000 \\
Penerimaan produksi & 250 Karung @ Rp. 10.000 & 2.500 .000 \\
Pendapat/produksi & & 1.600 .000 \\
R/C & & 1.3 \\
Efisensi Usaha & Total Biaya/Penerimaan & $76 \%$ \\
\hline
\end{tabular}

Sumber: Data primer, 2017

produsen sebesar 2,81 sehingga dapat disimpulkan bahwa usaha pengolahan gula sagu layak untuk dikembangkan.

\section{c. Analisis usaha pupuk organik}

Penerapan teknologi pemanfaatan limbah sagu untuk dijadikan pupuk organik dapat memberikan manfaat yang signifikan bagi petani terutama petani masyarakat lokal yang membudidayakan tanaman sayuran dan sejenisnya. Pemanfaatan limbah olahan sagu untuk menghasilkan pupuk organik mampu menekan pengeluaran terhadap kebutuhan pupuk bahkan menjadi alternatif jika terjadi kelangkaan pupuk anorganik di pasaran.

Analisis usaha penerapan teknologi pemupukan dengan menfaatkan limbah olahan sagu memperhitungkan biaya -biaya disajikan Pada Tabel 4.

Berdasarkan Tabel 4, total biaya produksi pupuk organik berbahan baku sagu adalah sebesar Rp 1.900.000/produksi, terdiri dari biaya tetap berupa peralatan seharga $\mathrm{Rp}$ 1.000 .000 dengan masa pakai selama dua tahun sehingga setiap tahun biaya peralatan adalah sebesar Rp 500.000 (26\%).

Sementara itu biaya varibael berupa bahan baku ampas sagu, kotoran sapi, bahan pendukung dan bahan bantu serta kemasan karung dan biaya tenaga kerja paruh waktu selama empat hari sebesar Rp 1.400.000 atau (74\%). Jika pupuk organik bahan baku sagu dihargai sebesar Rp 10.000/karung dan setelah dikurangi biaya produksi maka akan diperoleh pendapatan bersih sebesar Rp 1.600.000/ produksi. Hasil analisis kelayakan usaha ratio penerimaan dengan biaya menunjukkan bahwa usaha pembuatan pupuk organik layak untuk dikembangkan dengan nilai $\mathrm{R} / \mathrm{C}<1$ yaitu sebesar 1,3

\section{Kelembagaan Usaha Pertanian Bioindustri Berbasis Sagu}

Kelembagaan diartikan sebagai suatu institusi yang secara formal maupun informal berpengaruh dalam aktivitas pertanian bioindustri sagu secara berkelanjutan. Selain sebagai institusi maka kelembagaan pertanian bioindustri sagu juga mengandung makna perilaku, dan sistem nilai yang berkembang dalam masyarakat yang dijadikan modal dalam pembangunan. Adapun kelembagaan yang berperan sebagai aktor pendukung tercapainya pelaksaan bioindustri sagu yang dapat meningkatkan kesejahteraan secara berkelanjutan antara lain : (1) BUMDES/koperasi, (2) Pemerintah Kampung dan Perangkatnya, (3) Badan Musyawarah Kampus (Bamuskam), (4) Lembaga Masyarakat Adat, (5) Lembaga Gereja/tokoh Gereja, (6) Kelompok Wanita Gereja, (7) Penyuluh Pertanian, (8) Kelompok Taninelayan, (9) UPTD Kehutanan, (10) Lembaga Pendidikan, dan (11) Lembaga Kesehatan.

Dukungan kelembagaan akan berpengaruh nyata dalam kehidupan masyarakat dalam pengembangan pertanian bioindustri sagu. Kelembagaan sosial budaya seperti pemuka adat/ondoafi, kelembagaan pemerintah kampung, gereja dan kelembagaan 
lainnya berupa persekutuan pemuda, kaum ibu termasuk PKK dan sebagainya dapat menjalankan fungsi dan berperanan aktif sebagai motivator dalam pengembangan usaha.

Keberadaan kelembagaan ekonomi sebagai wadah memfaslitasi modal, sarana prasarana bahkan sebagai penampung hasil usahatani akan mendorong keberlanjutan pengembangan usaha masyarakat, termasuk tersedianya koperasi sebagai salah satu urat nadi perekonomian di kampung yang perlu dibina dengan pendampingan secara kontinu. Demikian pula keberadaan kelompok tani dan gapoktan dengan intensitas aktifitas yang kontinu dan berkelanjutan. Upaya terjalinnya hubungan erat dengan pihak pedagang komoditas pertanian sebagai wadah untuk memfasilitasi pemasaran produksi. Keberadaan dan dukungan Kelembagaan di wilayah produksi akan mampu meningkatkan manfaat dalam peningkatan produktivitas usaha.

Sementara itu penyuluh lapang di kampung dan key informan/local champion di wilayah produksi menjadi partner yang dapat menjalin hubungan harmonis menjadi pendamping dan motivator pengembangan usaha sekaligus sebagai jembatan penghubung dalam membangun jejaring pemasaran produk bioindustri.

Kontinuitas pembinaan dan pendampingan terhadap usaha sekaligus membangun jejaring pemasaran menjadi salah satu faktor penting memberikan manfaat dalam mengembangkan pertanian bioindustri sagu.

Produk-produk bioindustri sagu seperti halnya tepung sagu yang dihasilkan harus memiliki mutu yang baik sesuai standar SNI dan produknya kontinu, bersaing harganya, produk dikemas menarik juga informatif.

\section{KESIMPULAN DAN SARAN}

\section{Kesimpulan}

1. Model pertanian bioindustri sagu menghasilkan produk bahan baku pangan berupa tepung, dan bahan pangan gula sagu serta pemanfaatan limbah sagu menjadi pupuk organik dan merupakan suatu model pengembangan sagu ramah lingkungan.

2. Hasil analisis usaha menunjukan bahwa produk tepung sagu, gula sagu dan pupuk memberikan nilai manfaat bagi peningkatan pendapatan petani dan layak untuk dikembangkan. Tingkat kelayakan usaha $(\mathrm{R} / \mathrm{C})$ tepung sagu memiliki nilai $\mathrm{R} / \mathrm{C}$ sebesar 2,44 dan tingkat efisensi terhadap modal usaha $40,8 \%$. Gula sagu memiliki nilai R/C 2,81 dengan tingkat efisiensi 22,6\%. Pupuk organik limbah sagu memiliki nilai R/C 1,3 dengan tingkat efisiensi modal usaha sebesar $76 \%$.

\section{Saran}

Saran yang dapat dari hasil penelitian ini untuk pengembangan bioindustri kedepannya adalah perlunya pengembangan hutan sagu menjadi kawasan budidaya sagu yang berkelanjutan serta melibatkan semua pihak melalui pendekatan sosio budaya masyakat setempat.

\section{DAFTAR PUSTAKA}

APTINDO (Asosiasi Produsen Tepung Terigu Indonesia). (2016/2/17). Indonesia wheat flour consumption and growth. Retrieved from http://aptindo.or.id.

BPPT (Badan Pengkajian dan Penerapan). 1987. Penelitian pemanfaatan sagu sebagai bahan pembuatan makanan. Laporan Akhir. Kerjasama BPPT dengan pusat pengembangan teknologi pangan. Bogor: Institut Pertanian Bogor.

Bintoro, H.M.H., Hariyanto, B., Horigone, T., Marangkey, M.P., Sakaguchi, E., dan Takamura, Y. 1990. Feeding Value of Pith and Pith Residue from Sago Palm. Proceding Takahashi-Shi. Nutrition Conference, 1-12. Okayama.

Bintoro, H.M.H., Purwanto, M.Y.P., Amarillis, S. 2010. Sagu Di Lahan Gambut. Bogor: IPB Press.

Bintoro, D., Shandra, A., Ratih, K.D., dan Detieka, A. 2013. Sagu Hijau Mutiara Khatulistiwa yang Dilupakan. Bogor: Digregat Publishing.

Budiyanto, A. 2015. Bioindustri Sagu. Disampaikan pada pelatihan Diversifikasi Olahan Sagu di BPTP Sulawesi Tenggara, Kendari tanggal 23 Oktober 2015. 
Niki L., Petrus A. B. : Inovasi Model Bioindustri Berbasis Sagu ...

Flach, M. 1983. The Sago Palm: Domestication Exploitation and products. Rome: Food and Agriculture Organization of the United Nations.

Soekartawi. 1995. Analisis Usahatani. Jakarta: UI Press.
Wirakartakusumah, M.A., Eriyatno, Fardias, S., Thenawijaya, Muchtadi, D., dan Laksmie, J. 1984. Studi Tentang Ekstraksi, Sifat-sifat Fisikokimiawi Pati Sagu dan Pengkajian Enzima. Bogor: Institut Pertanian Bogor. 